\title{
KEMAMPUAN MAHASISWA DALAM MENGKONSTRUKSI BUKTI MATEMATIS PADA MATA KULIAH ANALISIS REAL
}

\author{
Ety Septiati \\ Pendidikan Matematika Universitas PGRI Palembang \\ etyseptiati@univpgri-palembang.ac.id
}

\begin{abstract}
ABSTRAK
Penelitian ini bertujuan untuk mengetahui kemampuan mahasiswa dalam mengkonstruksi bukti matematis pada mata kuliah Analisis Real. Subjek penelitian adalah mahasiswa semester V Program Studi Pendidikan Matematika Universitas PGRI Palembang yang sedang mengambil mata kuliah Analisis Real pada Tahun Akademik 2020/2021. Metode yang digunakan dalam penelitian ini adalah deskriptif kuantitatif. Kemampuan mengkonstruksi bukti matematis mahasiswa dilihat dari nilai tes yang diperoleh dalam penyelesaian soal yang telah disusun dengan mengacu pada indikator kemampuan mengkonstruksi bukti matematis. Data penelitian dianalisis menggunakan perhitungan statistika deskriptif. Hasil penelitian menunjukkan bahwa kemampuan mahasiswa dalam mengkonstruksi bukti matematis dominan berada pada indikator mengidentifikasi apa yang menjadi data dari pernyataan. Kemampuan mahasiswa dalam mengkonstruksi bukti matematis pada mata kuliah Analisis Real, yaitu: 6,5\% berada pada kategori Baik Sekali, 35,5\% kategori baik, 29\% kategori cukup dan 29\% masih berada pada kategori tidak mampu membaca bukti.
\end{abstract}

Kata kunci : konstruksi bukti matematis, analisis real

\begin{abstract}
The purpose of this study is to assess students' ability to construct mathematical proofs in the Real Analysis course. Students in the fifth semester of the Mathematics Education Study Program at the University of PGRI Palembang who were taking the Real Analysis course in the 2020/2021 Academic Year served as research subjects. The descriptive quantitative method was used in this study. The test scores obtained in solving problems prepared with reference to the indicators of the ability to construct mathematical evidence reveal students' ability to construct mathematical evidence. Descriptive statistical calculations were used to analyze the research data. The findings revealed that the students' ability to construct mathematical evidence was the most important predictor of identifying what the data from the statement were. Students' ability to construct mathematical proofs in the Real Analysis course, with $6.5 \%$ in the Very Good category, $35.5 \%$ in the Good category, $29 \%$ in the Sufficient category, and $29 \%$ in the Unable to Read Evidence category.
\end{abstract}

Keywords : construct mathematical proofs, real analysis 


\section{PENDAHULUAN}

Salah satu mata kuliah yang wajib ditempuh oleh mahasiswa pendidikan matematika adalah Analisis Real. Melalui perkuliahan Analisis Real, mahasiswa diharapkan mampu: a) memiliki pengetahuan dasar analisis matematika, khususnya tentang bilangan, barisan, fungsi, limit, dan turunan, b) bernalar secara logis dan mengekspresikan hasil penalarannya secara tertulis, sistematis dan rigorous. Mata kuliah ini membekali mahasiswa kemampuan bernalar yang merupakan salah satu dari kemampuan matematika (mathematic competence). Pengetahuan prosedural mahasiswa yang diperoleh dari mata kuliah Kalkulus 1, Kalkulus 2, dan Kalkulus Lanjut akan diperdalam pada mata kuliah Analisis Real agar mahasiswa tidak hanya berpikir prosedural (procedural thinking) akan tetapi juga memiliki kemampuan berpikir logis (logically thinking) (Syawahid, 2015:142).

Mata kuliah Analisis Real adalah salah satu mata kuliah yang cukup ketat dalam memberlakukan sistem deduktif aksiomatik sehingga cukup ditakuti bagi sebagian besar mahasiswa. Pemahaman definisi formal sampai pembuktian dan sifatsifatnya merupakan tantangan tersendiri bagi mahasiswa. Permasalahan yang paling menonjol dihadapi dalam perkuliahan Analisis Real adalah terjadinya miskonsepsi mahasiswa terhadap materi sehingga menyulitkan dalam pembuktian (Wahyuni, 2017:148). Mahasiswa sering mengatakan bahwa mereka dapat memahami bukti yang diberikan dosen di depan kelas, tetapi ketika diminta melakukannya di rumah, mereka mengalami kesulitan membuktikan sendiri (Barnard, 2000). Padahal peran pembuktian dalam kurikulum matematika adalah sebagai kunci utama untuk menunjukkan pemahaman matematis (Hanna, 1995).

Dalam matematika, bukti adalah serangkaian argumen logis yang menjelaskan kebenaran suatu pernyataan. Argumen-argumen ini dapat berasal dari premis pernyataan itu sendiri, teorema-teorema lainnya, definisi, dan akhirnya dapat berasal dari postulat dimana sistem matematika tersebut berasal. Yang dimaksud logis di sini, adalah semua langkah pada setiap argumen harus dijustifikasi oleh langkah sebelumnya (Hernadi, 2008). Peran utama bukti di dalam praktek matematika adalah verifikasi dan pembenaran, tetapi di dalam bidang pendidikan matematika, bukti lebih banyak digunakan untuk penjelasan (Hanna, 1995).

Menurut Selden dan Selden (2003), kemampuan pembuktian matematis terdiri dari : (1) kemampuan mengkonstruksi bukti dan (2) kemampuan memvalidasi bukti. Moore (Weber, 2001) mengungkapkan bahwa siswa hanya akan mendapatkan sedikit pelajaran tentang matematika lanjut (advanced mathematics), bila mereka secara pasif hanya menulis bukti yang diberikan oleh pengajarnya di papan tulis, sementara siswa akan banyak belajar tentang konsep matematika dan bukti apabila mereka mencoba mengkonstruksi bukti sendiri. Pada kenyataannya, bagaimana menyusun atau mengkonstruksi suatu bukti juga merupakan masalah bagi mahasiswa. Mereka tidak paham bukti dan tidak tahu bagaimana harus memulai sebuah pembuktian.

Kemampuan mengkonstruksi bukti adalah kemampuan menyusun suatu bukti pernyataan matematik berdasarkan definisi, prinsip, dan teorema, serta menuliskannya dalam bentuk pembuktian lengkap (pembuktian langsung atau tak langsung). Kemampuan ini meliputi: kemampuan mengidentifikasi premis beserta implikasinya dan kondisi yang mendukung; kemampuan mengorganisasikan dan memanipulasi fakta untuk menunjukkan kebenaran suatu pernyataan; kemampuan membuat koneksi antara fakta dengan unsur dari konklusi yang hendak dibuktikan (Sumarmo, 2003). Kemampuan mahasiswa dalam mengkonstruksi bukti sangat 
menentukan keberhasilannya mempelajari matematika tingkat lanjut, sehingga penelitian untuk mengungkap fenomena ini penting dilakukan (Darmawan, 2016:154).

Berdasarkan uraian di atas, maka penelitian ini bertujuan untuk mengetahui bagaimana kemampuan mahasiswa dalam mengkonstruksi bukti matematis pada mata kuliah Analisis Real.

\section{METODE}

Penelitian ini merupakan penelitian deskriptif kuantitatif. Subjek penelitian adalah mahasiswa semester V Program Studi Pendidikan Matematika Universitas PGRI Palembang yang sedang mengambil mata kuliah Analisis Real pada Tahun Akademik 2020/2021.

Prosedur penelitian terdiri dari 3 (tiga) tahapan, yaitu: perencanaan, pelaksanaan, dan analisis serta evaluasi. Adapun masing-masing tahapan dapat diuraikan sebagai berikut: 1) Pada tahap perencanaan, dipersiapkan instrumen penelitian berupa soal tes yang sesuai dengan indikator mengkonstruksi bukti dan membuat kunci jawaban. Selanjutnya validasi soal tes ke pakar. Setelah dinyatakan valid, soal siap diujikan ke subjek penelitian; 2) Pada tahap pelaksanaan, soal tes dikerjakan mahasiswa sesuai dengan alokasi waktu yang diberikan. Mahasiswa mengerjakan 3 (tiga) buah soal Analisis Real selama 60 menit. Soal tes yang dibuat dalam bentuk uraian yang mengacu pada indikator kemampuan mengkonstruksi bukti matematis. Jawaban siswa dikoreksi dan diberikan skor sesuai Tabel 1. Pedoman penskoran yang digunakan merupakan modifikasi dari Perbowo dan Pradipta (2017) sebagai berikut:

Tabel 1. Pedoman penskoran

\begin{tabular}{cl}
\hline Skor & \multicolumn{1}{c}{ Keterangan } \\
\hline 4 & Jawaban lengkap dan benar \\
3 & Jawaban lengkap dan salah \\
2 & Jawaban tidak lengkap \\
1 & Menunjukkan kasus \\
0 & Tidak dapat menuliskan jawaban \\
\hline
\end{tabular}

Selanjutnya, total skor yang diperoleh setiap mahasiswa dikonversikan menjadi nilai dalam rentang $0-100$ dengan menggunakan rumus:

$$
\text { nilai }=\frac{\text { total skor }}{\text { skor maksimal }} \times 100
$$

Skor maksimal yang bisa diraih mahasiswa dalam tes adalah 60 ; 3) Pada tahap analisis, data hasil kemampuan mengkonstruksi bukti matematis mahasiswa yang diperoleh melalui pemberian soal tes dianalisis sehingga mendapatkan suatu kesimpulan.

Teknik analisis data yang digunakan adalah perhitungan statistika deskriptif dan penarikan kesimpulan/verifikasi. Pada tabel 2 disajikan indikator kemampuan mengkonstruksi bukti yang digunakan. Selanjutnya, kriteria pencapaian indikator kemampuan mengkonstruksi bukti disajikan dalam tabel 3. 
Tabel 2. Indikator kemampuan mengkonstruksi bukti matematika

\begin{tabular}{|c|c|c|}
\hline Variabel & Indikator & Kode \\
\hline \multirow{5}{*}{$\begin{array}{l}\text { Kemampuan } \\
\text { mengkonstruksi } \\
\text { bukti matematika }\end{array}$} & $\begin{array}{l}\text { 1. Mengidentifikasi apa yang menjadi data } \\
\text { dari pernyataan }\end{array}$ & $\mathrm{M}_{1}$ \\
\hline & $\begin{array}{l}\text { 2. Mengidentifikasi apa yang menjadi } \\
\text { conclusion dari pernyataan }\end{array}$ & $\mathrm{M}_{2}$ \\
\hline & $\begin{array}{l}\text { 3. Menyatakan keterkaitan di antara data } \\
\text { dan antara data dengan konklusi dengan } \\
\text { menunjukkan suatu warrant }\end{array}$ & $\mathrm{M}_{3}$ \\
\hline & $\begin{array}{l}\text { 4. Membuat dugaan mengenai konsep } \\
\text { kunci yang menjembatani antara data } \\
\text { dan konklusi (konjektur) }\end{array}$ & $\mathrm{M}_{4}$ \\
\hline & $\begin{array}{l}\text { 5. Mengevaluasi aturan-aturan penarikan } \\
\text { kesimpulan dari fakta-fakta yang } \\
\text { diberikan atau yang diperoleh secara } \\
\text { kritis (kaidah inferensi). }\end{array}$ & $\mathrm{M}_{5}$ \\
\hline
\end{tabular}

(Sumarmo dikutip Faruq, 2014)

Tabel 3. Kriteria mengkonstruksi bukti matematika

\begin{tabular}{ll}
\hline \multicolumn{1}{c}{$\begin{array}{c}\text { Kriteria kemampuan mengkonstruksi } \\
\text { bukti matematika }\end{array}$} & \multicolumn{1}{c}{ Pencapaian indikator } \\
\hline Baik sekali & M1, M2, M3, M4, M5 \\
Baik & M1, M2, M3, M4 \\
Cukup & M1, M2, M3 \\
Tidak mampu membaca bukti & Tidak mampu memenuhi salah satu \\
& atau lebih dari indikator M1, M2, M3 \\
\hline
\end{tabular}

(Modifikasi Faruq, 2014)

\section{HASIL DAN PEMBAHASAN}

Berdasarkan hasil perhitungan statistik menggunakan Microsoft Excel, deskripsi statistik data penelitian disajikan pada tabel 4 .

Tabel 4. Statistika deskriptif data penelitian

\begin{tabular}{lc}
\hline \multicolumn{1}{c}{ Statistik } & Nilai \\
\hline Mean & 43,7 \\
Median & 43,3 \\
Mode & 75,0 \\
Standard deviation & 22,0 \\
Range & 75,0 \\
Minimum & 6,7 \\
Maximum & 81,7 \\
Count & 31,0 \\
\hline
\end{tabular}


Berdasarkan tabel 4, meskipun nilai yang paling banyak diperoleh mahasiswa adalah 75 , akan tetapi rentang nilai yang cukup jauh antara nilai maksimum dan minimum diduga menyebabkan rendahnya kemampuan mahasiswa dalam mengkonstruksi bukti matematis secara rata-rata, yakni hanya mencapai nilai 43,7 (dari skala 0-100) dengan median 43,3. Nilai minimum yang diraih adalah 6,7 , artinya jumlah skor yang diraih hanya 4 dari total skor maksimal 60 . Hal ini diperkuat dengan hasil analisis data pada tabel 5 .

Tabel 5. Distribusi frekuensi kemampuan mengkonstruksi bukti matematis

\begin{tabular}{lcc}
\hline \multicolumn{1}{c}{ Kategori } & Frekuensi & $\%$ \\
\hline Baik sekali & 2 & 6.5 \\
Baik & 11 & 35.5 \\
Cukup & 9 & 29.0 \\
Tidak mampu membaca bukti & 9 & 29.0 \\
\hline
\end{tabular}

Berdasarkan tabel 5, sebanyak 9 subjek (29\%) berada pada kategori tidak mampu membaca bukti, artinya, dari 3 soal yang diberikan rata-rata skor yang diraih hanya berada pada rentang 0 sampai dengan 1. Dengan kata lain, dari 5 indikator yang diukur, subjek hanya mampu menuliskan kasus atau menulis ulang pernyataan yang akan dibuktikan. 9 subjek (29\%) berada pada kategori cukup mampu membaca bukti. 11 subjek $(35,5 \%)$ berada pada kategori baik dalam membaca bukti. Hanya 2 subjek penelitian $(6,5 \%)$ yang mencapai kategori Baik sekali.

Pada tabel 6 ditampilkan rata-rata skor kemampuan mahasiswa dalam mengkonstruksi bukti pada setiap indikator.

Tabel 6. Rata-rata skor tiap indikator

\begin{tabular}{lc}
\hline \multicolumn{1}{c}{ Indikator } & Rata-rata \\
\hline $\begin{array}{l}\text { 1. Mengidentifikasi apa yang menjadi data dari } \\
\text { pernyataan }\end{array}$ & 2.5 \\
\hline $\begin{array}{l}\text { 2. Mengidentifikasi apa yang menjadi conclusion dari } \\
\text { pernyataan }\end{array}$ & 1.9 \\
\hline $\begin{array}{l}\text { 3. Menyatakan keterkaitan di antara data dan antara } \\
\text { data dengan konklusi dengan menunjukkan suatu } \\
\text { warrant }\end{array}$ & 1.7 \\
\hline $\begin{array}{l}\text { 4. Membuat dugaan mengenai konsep kunci yang } \\
\text { menjembatani antara data dan konklusi } \\
\text { (konjektur). }\end{array}$ & 1.2 \\
\hline $\begin{array}{l}\text { 5. Mengevaluasi aturan-aturan penarikan } \\
\text { kesimpulan dari fakta-fakta yang diberikan atau } \\
\text { yang diperoleh secara kritis (kaidah inferensi) }\end{array}$ & 1.4 \\
\hline
\end{tabular}

Berdasarkan tabel 6, diketahui bahwa secara rata-rata skor tertinggi yang dicapai adalah pada indikator 1 mengidentifikasi apa yang menjadi data dari pernyataan. Dari 31 data yang ada, hanya 13 orang yang mampu mengidentifikasi secara lengkap fakta apa yang diketahui dari pernyataan matematik yang akan dibuktikan kebenarannya. Hal ini ditunjukkan oleh perolehan skor 3 dan 4 . 
Sedangkan terdapat 4 subjek penelitian yang meraih skor 0 pada indikator ini. Ratarata skor terendah ada pada indikator keempat, membuat dugaan mengenai konsep kunci yang menjembatani antara data dan konklusi (konjektur). Terdapat 12 jawaban yang mendapat skor 0 untuk indikator ini. Artinya, 12 mahasiswa tidak dapat membuat dugaan gagasan utama dalam melakukan pembuktian.

Pada tabel 7 berikut ini disajikan rata-rata skor pada tiap nomor soal.

Tabel 7. Rata-rata skor tiap soal

\begin{tabular}{cc}
\hline Nomor soal & Rata-rata \\
\hline 1 & 2.4 \\
2 & 1.4 \\
3 & 1.5 \\
\hline
\end{tabular}

Berdasarkan tabel 7, rata-rata skor tertinggi berada pada soal nomor 1. Adapun soal nomor 1, yaitu membuktikan fakta bahwa $(-1) .(-1)=1$. Sedangkan rata-rata skor terendah pada soal nomor 2 , yaitu membuktikan bahwa $\left[\frac{1}{2}(a+b)\right]^{2} \leq \frac{1}{2}\left(a^{2}+b^{2}\right)$ $\Leftrightarrow a=b, \forall a, b \in R$. Pembuktian kedua soal tersebut merupakan pembuktian langsung, dimana untuk soal nomor 2 merupakan bentuk biimplikasi. Salah satu kekeliruan yang dilakukan subjek penelitian adalah hanya melakukan pembuktian pada 1 arah saja. Hal ini senada dengan yang terjadi pada penelitian Hadi (2016:82). Pada gambar 1 dan gambar 2 disajikan beberapa jawaban mahasiswa pada soal nomor 2.

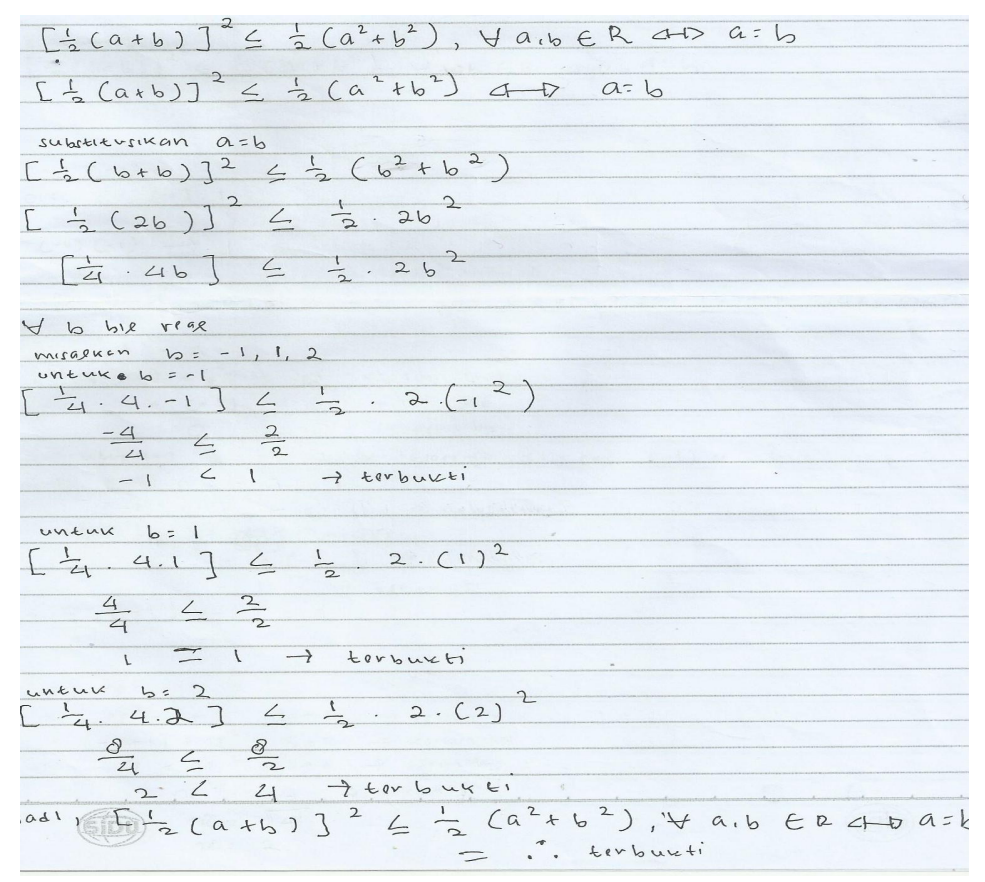

Gambar 1. Jawaban subjek AS pada soal nomor 2 


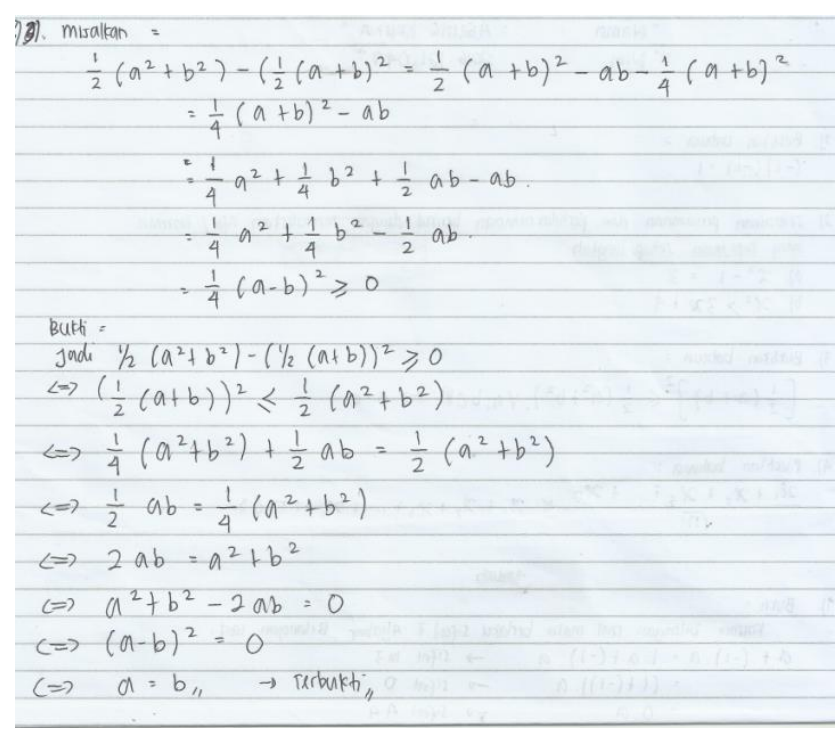

Gambar 2. Jawaban subjek AK pada soal nomor 2

Soal nomor 3, dapat dibuktikan dengan prinsip induksi matematika. Menurut Taufik (2016:46), tidak sebarang situasi bisa dibuktikan dengan induksi matematika, namun ada beberapa situasi/kategori khusus pembuktian dengan induksi matematika, kategori-kategori yang dimaksud, sebagaimana dijelaskan oleh Morash (1991) adalah rumus penjumlahan yang biasa dinyatakan sebagai makna notasi jumlah dengan lambang $\Sigma$, generalisasi dari dua objek ke dalam sebarang bilangan terbatas. Dari 31 subjek penelitian, hanya 1 mahasiswa yang mampu melakukan pembuktian dengan metode ini. Cuplikan jawaban subjek ini disajikan pada gambar 3 .

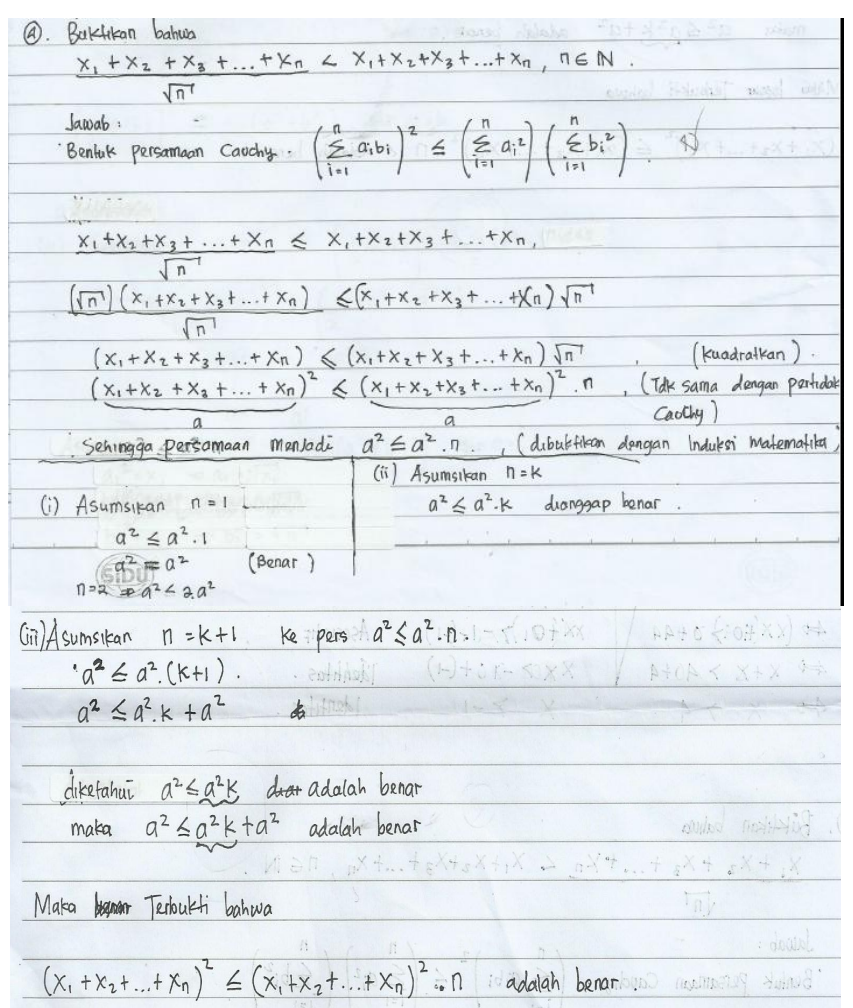

Gambar 3. Jawaban subjek pada Soal nomor 3 yang mendapat skor maksimum 


\section{SIMPULAN DAN SARAN}

Berdasarkan hasil analisis data, dapat disimpulkan sebagai berikut: 1) Kemampuan mahasiswa dalam mengkonstruksi bukti matematis dominan berada pada indikator mengidentifikasi apa yang menjadi data dari pernyataan. 2) Kemampuan mahasiswa dalam mengkonstruksi bukti matematis pada mata kuliah Analisis Real, yaitu: 6,5\% berada pada kategori Baik Sekali, 35,5\% kategori baik, $29 \%$ kategori Cukup, dan 29\% masih berada pada kategori tidak mampu membaca bukti.

Disarankan kepada dosen pengampu mata kuliah Analisis Real ataupun mata kuliah lain yang sejenis dengan mata kuliah analisis ini untuk dapat menggunakan metode maupun media pembelajaran yang dapat melatih serta meningkatkan kemampuan mahasiswa dalam mengkonstruksi bukti matematik, karena kemampuan mengkonstruksi bukti matematik merupakan kemampuan yang sangat mendasar dalam memahami inti matematika.

\section{DAFTAR PUSTAKA}

Barnard, T. 2000. Why Are Proofs Difficult? The Mathematical Gazette, Vol. 84(501) : 415-422. [Online]. Tersedia: http://www.jstor.org.

Darmawan, P. 2016. Berpikir Analitik Mahasiswa dalam Mengkonstruksi Bukti Secara Sintaksis. Jurnal Pendidikan Matematika, Vol. 2(2) : 154-165.

Faruq, A. 2014. Analisis Struktur Argumentasi dan Kemampuan Mengkonstruksi Bukti Matematika Siswa Sekolah Menengah. Skripsi tidak diterbitkan. Surabaya: UIN Sunan Ampel Surabaya.

Hadi, S. 2016. Kemampuan Mahasiswa dalam Mengkonstruksi Bukti Bentuk Biimplikasi Ditinjau dari Tingkat Kecemasan. JIPMat (Jurnal Ilmiah Pendidikan Matematika), Vol. 1(1) : 79-87.

Hanna, G. 1995. Challenge to the Importance of Proof. For the Learning of Mathematics, 15(3).Canada: FLM Publishing Association.

Hernadi, J. 2008. Metoda Pembuktian dalam Matematika. Jurnal Pendidikan Matematika, Vol. 2(1) : 1-13.

Morash, R. P. 1991. Bridge to Abstrac Mathematics : Mathematical Proof and Structure. New York: McGraw-Hill.inc.

Perbowo, K. S. dan Pradipta, T. R. 2017. Pemetaan Kemampuan Pembuktian Matematis Sebagai Prasyarat Mata Kuliah Analisis Real Mahasiswa Pendidikan Matematika. Kalamatika, Vol. 2(1) : 81-90.

Sumarmo, U. 2003. Advanced Mathematical Thinking dan Habit of Mind Mahasiswa. Bahan Ajar Mata Kuliah Kajian dan Isu Pendidikan Matematika Pascasarjana UPI dan STKIP Siliwangi Bandung. [Online]. Tersedia: https://docplayer.info/40412699-Advanced-mathematical-thinking-dan-habitof-mind-mahasiswa.html

Selden, A. and Selden, J. 2003. Validation of Proof Considered as Texts: Can Undergraduates Tell Whether an Argument Proves a Theorem? Journal for Research Mathematics Education, Vol. 34(1) : 4-36.

Syawahid, M. 2015. Kemampuan Berpikir Formal Mahasiswa. Beta : Jurnal Pendidikan Matematika, Vol. 8(2) : 125-141. 
Taufik, A. 2016. Diagnosis Kesulitan Mahasiswa di Universitas Kuningan dalam Pembuktian Menggunakan Induksi Matematika Beserta Upaya Mengatasinya Menggunakan Scaffolding. JES-MAT, Vol. 2(1) : 41-54.

Wahyuni, M. 2017. Analisis Problematika Perkuliahan Analisis Real. Jurnal Cendekia: Jurnal Pendidikan Matematika, Vol. 1(1) : 135-149.

Weber, K. 2001. Student Difficulty in Constructing Proofs : The Need for Strategic Knowledge. Educational Studies in Mathematics, Vol. 48 : 101-119. 